\title{
Georgiy Shkabarin
}

University of Warsaw

e-mail: gshkabarin@wne.uw.edu.pl

\section{FDI SPILLOVERS IN TRANSITIVE}

ECONOMIES INTEGRATING INTO THE EU

IN CASE OF THE BALTIC COUNTRIES

\section{EFEKTY POŚREDNIE BIZ W GOSPODARKACH PRZEJŚCIOWYCH INTEGRUJĄCYCH SIĘ Z UE NA PRZYKŁADZIE KRAJÓW BALTYCKICH}

DOI: $10.15611 / \mathrm{e} 21.2015 .4 .02$

JEL Classification: F21, F23

\begin{abstract}
Summary: The paper deals with the idea of spillovers (or indirect effects) from foreign direct investment increasing the firm productivity in transitive economies under the circumstances of economic integration. The Baltic countries are the best example of such a kind of states. The indirect effects for the productivity are examined both at a country and at a firm level with the use of a proved estimation model in order to probe for the existence, sign and magnitude of different types of spillovers. The paper includes a brief historical analysis of the previous works and the history of elaboration of an estimation model for spillovers. The analysis of FDI inflows in Estonia, Latvia and Lithuania with diagrams is included to visualize the change in the attitude of foreign investors to these countries during the post-soviet period and after their accession to the EU.
\end{abstract}

Keywords: FDI, spillovers, productivity, Latvia, Lithuania, Estonia.

Streszczenie: Temat artykułu dotyczy koncepcji spillowerów (efektów pośrednich) BIZ, które zwiększają wydajność firm w krajach, przechodzących od gospodarki centralnie planowanej do gospodarki rynkowej, w warunkach integracji ekonomicznej. Kraje bałtyckie są najlepszym przykładem takiego rodzaju państw. Efekty pośrednie zostały rozpatrzone na poziomie państw oraz na poziomie firmowym za pomocą modelu ekonometrycznego dla sprawdzenia istnienia, znaku oraz wielkości różnych typów spillowerów. Artykuł zawiera krótką analizę historyczną poprzednich prac w tym zakresie oraz analizę napływu BIZ do krajów bałtyckich z wykresami dla wizualizacji zmian w postawie inwestorów zagranicznych do tych państw w okresie transfrormacji postradzieckiej oraz po wstąpieniu do Unii Europejskiej.

Słowa kluczowe: BIZ, spillowery, efekty pośrednie, wydajność, Łotwa, Litwa, Estonia. 


\section{Introduction}

The problem of the FDI spillovers is widely discussed in the scientific literature for more than 40 years. As Crespo and Fontoura [2007] remark, in most countries, foreign direct investment is considered to be an important component of development strategy and policies are designed accordingly in order to stimulate inward flows. The concept of spillovers from FDI represents the idea that multinational enterprises (MNEs or MNCs) own technology that includes "both product, process, and distribution technology, as well as management and marketing skills" [Blomström, Kokko 1998, p. 247], which can be transmitted to domestic enterprises in direct or indirect way and thus increase their level of productivity. The literature on the determinants of FDI accentuates that multinationals have certain superiorities that "might be related to their large endowments of intangible assets, such as superior technologies, patents, trade secrets, brand names, management techniques, and marketing strategies, among others" [Dunning 1993].

The main goal of this paper is to verify the existing of the FDI spillovers in the Baltic countries, during the period of 2003-2011, to check their sign and to find out to which extent the entry of foreign investors affects the productivity of local firms in small open transitive economies, to which the Baltic states belong.

In this paper the broader range of sectors than in many other studies is employed; not only manufacturing companies are taken into account, but also those belonging to wholesale and retail sectors, agriculture, etc. In the conditions of the European economic integration these sectors are usually influenced by large capital inflows while they are often omitted during estimations.

This paper is also aimed to test the hypothesis that forward spillovers in transitive economies that are affected by the integration processes and export mostly to other countries of the union tend to be negative due to the extrusion of domestic firms, not satisfying the EU standards by foreign companies that offer the same products of higher standards but at higher prices.

\section{Literature overview}

The early works on the theme mostly using country-level and sector-level data for the cases of developed and developing countries appeared more than 40 years ago. It is often considered that the foundations of the idea of FDI spillovers were laid in the work of Caves [1974]. The scholar came to the conclusion that local firms competing in sectors with a higher FDI presence have greater productivity levels. This work was also the first using productivity of domestic companies as the measure of the FDI effect. Blomström [1986] came to a conclusion that there was a positive correlation between the presence of MNEs in an industry and the structural efficiency. However, foreign entry leads in his opinion to structural changes only in the "modern" part of the sectors. Rhee and Belot [1990] claimed in their study that the creation and 
growth of domestic firms depended largely on the entry of foreign firms. They regarded the diffusion of the foreign know-how the main channel of the positive spillovers for the domestically-owned companies.

However, before the appearance of the works by Damijan et al. [2003] and Javorcik et. al. [2004], even the quite obvious fact of positive FDI spillovers existence, proved repeatedly on the example of aggregated data, was called into question. The lack of studies demonstrating the presence of the positive spillovers from foreign investment with the use of firm-level data was remaining the main obstacle. By that moment there existed a group of articles based on firm-level data that examined the correlation between the productivity of domestic firms and the extent of foreign presence within their sector (horizontal spillovers) using their own methods (Aitken and Harrison [1999] for Venezuela, Konings [2001] on Romania, Bulgaria and Poland, and Djankov and Hoekman [2000] on the Czech Republic) and found little signs of positive effects or even no evidence for them. The positive picture of FDI spillovers shown before at country-level and sector-level was rejected by abovementioned authors because of difficulty in determining the direction of causation. It was argued that positive linkage between FDI inflow and the domestic firms' productivity may be caused not by the FDI spillovers themselves but by the fact that MNCs usually locate their investment in high-productivity and high-income sectors. The positive correlation was also named a result of fact that FDI inflows force less productive domestic firms to exit whilst more productive multinationals increase their share of host country market, in both cases raising the average productivity in the industry [Javorcik 2004].

It's important to notice that all of these works had the same feature: as Blomstróm et al. [2000] pointed out, nearly none of empirical studies of the time employed vertical spillovers (i.e. spillovers that may appear between the foreign subsidiary and the domestic firms from supplying sectors or sectors supplied by a company with foreign capital). The only notable exceptions of that period were the papers by Blalock [2001] and by Schoors and van der Tol [2001]. In both works the existence of positive vertical spillovers from FDI was confirmed.

On the whole by the moment of elaboration of a stable enough system of spillover evaluation, a negative impact was reported in 12 studies, while the existence of productivity spillovers was not confirmed in 31 cases and only 17 studies pointed to the existence of a positive impact [Lipsey 2002].

Certain changes happened in 2003 after the release of the work of Damijan et al., and in 2004 after the appearance of study by Javorcik. By the present day these two works have formed the series of succeeding papers of different authors using similar approaches to the estimation strategy.

The paper of Damijan et al. [2003] uses the methodology invented by Blalock [2001] for the calculation of horizontal and vertical spillovers and in order to differentiate between forward and backward vertical linkages (i.e. between the spillovers in sectors supplied by the foreign-owned company and supplying it 
respectively). The gross output of firms is used as a dependent variable in the model. It depends on the number of employees, technology, capital stock, and materials used in production. Two independent variables measuring separately horizontal and vertical linkages between local and foreign companies were also included into the model.

The idea of Javorcik [2004] follows the development of those earlier researchers improving their model. Since that time, most of the following papers, dividing the spillovers into horizontal and vertical ones, have found the evidence of positive effects of FDI in upstream and downstream sectors (backward and forward spillovers). Modern researches (Du, Harrison and Jefferson [2012], Xu and Sheng [2012], Suyanto, Salim and Bloch [2012], Suyanto and Salim [2013], Merlevede, Schoors and Spatareanu [2013], Damijan et al. [2013] and others) have proved the efficiency of this model, concentrating on the details of spillover transmission processes.

Therefore, in the particular case of this work the proved model of Damijan et al. and Javorcik is used for the estimation, while the article in whole tries to answer the question of the influence of integration processes on the sign and magnitude of spillover effects from FDI. The opinions about such influence differ. For instance, Stancik [2009] shows on an example of the Czech Republic that positive forward spillovers were present mainly in the years after the integration into the EU. Javorcik, Saggi and Spatereanu [2004] declare that the preferential trade agreements (or free trade abilities in case of the EU) affect the inputs supply chains in the following manner. The investors from EU countries have a greater incentive to buy inputs in their home countries than in a recipient country. Thus, if the recipient country is the EU member, we can expect low backward spillovers. The estimation in the current article will show the applicability of this idea to the Baltic countries.

The following section of the article describes the features of FDI inflow in Estonia, Latvia and Lithuania and the dependence between aggregated data of Labor Productivity and FDI inflow.

\section{FDI inflow in Baltic countries}

The simple analysis of the FDI inflows into the Baltic countries shows that the data from 1992 to 2003 can give little for the research as during this period all given countries were not of particular interest to the foreign investors (see Figure 1 and Table 1).

Only after the clear signals of the future accession into the EU (e.g. the referendum on the accession into the EU which took place on $20^{\text {th }}$ of September 2003 in Latvia), the investors started to purchase shares in the equity capitals of local companies of the Baltic countries. This period was marked by a record boost in the FDI inflow in all of these countries. 


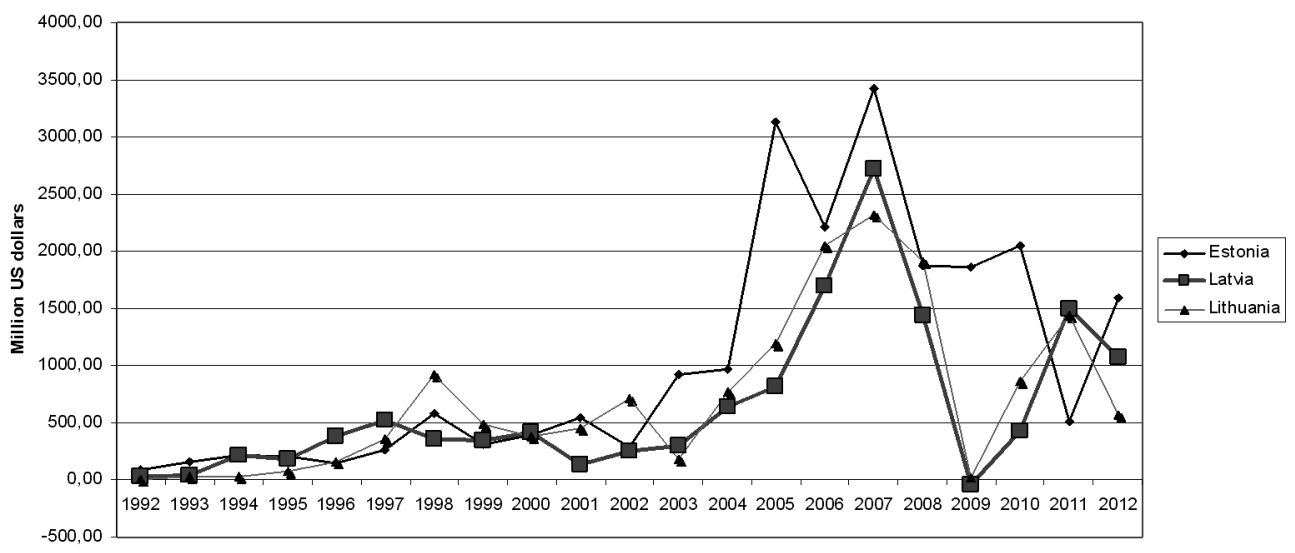

Figure 1. Foreign direct investment in Baltic countries, 1992-2012

Source: own rendering based on International Monetary Fund data.

Table 1. The ratio between FDI and GDP/FDI inflow per capita of Baltic countries, 1992-2012

\begin{tabular}{|l|r|c|c|c|c|c|}
\hline \multirow{2}{*}{} & \multicolumn{2}{|c|}{ Estonia } & \multicolumn{2}{c|}{ Latvia } & \multicolumn{2}{c|}{ Lithuania } \\
\cline { 2 - 7 } & FDI/GDP & $\begin{array}{c}\text { FDI } \\
\text { in per capita }\end{array}$ & FDI/GDP & $\begin{array}{c}\text { FDI } \\
\text { in per capita }\end{array}$ & FDI/GDP & $\begin{array}{c}\text { FDI } \\
\text { in per capita }\end{array}$ \\
\hline 1992 & n.a. & 53.66 & 0.61 & 11.25 & n.a. & n.a. \\
\hline 1993 & n.a. & 108.57 & 1.01 & 17.60 & 0.41 & 8.19 \\
\hline 1994 & n.a. & 146.62 & 4.24 & 85.08 & 0.45 & 8.56 \\
\hline 1995 & 4.62 & 140.25 & 3.43 & 72.28 & 0.92 & 19.99 \\
\hline 1996 & 3.17 & 106.12 & 6.83 & 155.34 & 1.81 & 42.31 \\
\hline 1997 & 5.26 & 190.22 & 8.50 & 214.17 & 3.50 & 99.16 \\
\hline 1998 & 10.35 & 418.80 & 5.39 & 148.09 & 8.22 & 260.76 \\
\hline 1999 & 5.34 & 221.05 & 4.77 & 145.41 & 4.43 & 138.03 \\
\hline 2000 & 6.81 & 277.25 & 5.27 & 174.23 & 3.31 & 108.26 \\
\hline 2001 & 8.70 & 390.81 & 1.59 & 56.48 & 3.67 & 128.45 \\
\hline 2002 & 3.89 & 206.27 & 2.72 & 109.78 & 5.03 & 206.92 \\
\hline 2004 & 8.01 & 708.83 & 4.63 & 281.43 & 3.41 & 228.94 \\
\hline 2005 & 22.33 & 2308.35 & 5.06 & 362.61 & 4.56 & 357.87 \\
\hline 2006 & 13.05 & 1642.53 & 8.54 & 767.41 & 6.78 & 627.57 \\
\hline 2007 & 15.43 & 2557.69 & 9.43 & 1233.23 & 5.91 & 719.61 \\
\hline 2008 & 7.75 & 1400.99 & 4.26 & 659.02 & 4.02 & 596.71 \\
\hline 2009 & 9.50 & 1398.80 & -0.17 & -20.54 & 0.05 & 6.05 \\
\hline 2010 & 10.54 & 1541.83 & 1.80 & 206.43 & 2.35 & 278.58 \\
\hline 2011 & 2.24 & 384.72 & 5.27 & 729.37 & 3.35 & 476.56 \\
\hline 2012 & 7.03 & 1203.69 & 3.79 & 529.07 & 1.36 & 192.13 \\
\hline
\end{tabular}

Source: own calculations based on International Monetary Fund, Balance of Payments database, official national sources, World Bank national accounts data. 
The analysis of data from Table 1 shows that the ratio between FDI and GDP was the highest in Estonia in most of the years, while in Lithuania it was the lowest. This fact is confirmed with the data of FDI inflow per capita. Average value of this indicator makes up 801.19, 302.96 and 227.86 US dollars in Estonia, Latvia and Lithuania respectively.

The period from 2003 to 2011 gives wider possibilities for the analysis of FDI in the Baltic countries and their influence on the productivity of local companies. This period is characterized in all of the countries by the sample with strong boost during the period 2004-2007 and a sharp cut off which falls on the periods 2008-2009 for Latvia and Lithuania and 2010-2011 for Estonia. In the first two countries the cause was the economic crisis 2008-2010, while Estonia had a higher degree of safety. The drop in the FDI in Estonia is mostly associated with the introduction of euro.

The simple rough search of dependence between aggregated data of labor productivity and FDI inflow during the period 1992-2012 in the Baltic countries gives the following data. The elasticity coefficients between these two indicators make up $0.473\left(R^{2}=0.51\right)$ in case of Estonia, $0,43\left(R^{2}=0.42\right)$ for Latvia and 0.466 $\left(\mathrm{R}^{2}=0.43\right)$ for Lithuania. It means that according to the aggregated data analysis, $1 \%$ growth of FDI inflow may lead to the corresponding growth of labor productivity in percent for each country. The following more accurate estimation based on firmlevel data will show how these productivity benefits from FDI are distributed between local firms according to the direction of their connections with the foreign-owned companies.

\section{Estimation strategy}

In this study FDI spillovers in the Baltic countries are analyzed at the firm-level. The research is based on the modified model of Javorcik [2004] which is used for the estimation of the relationship between the productivity of the domestic firm and certain determinants.

The general view of the equation is:

$$
\begin{aligned}
\ln Y_{i p}=\alpha & +\beta 1 \ln K_{i t}+\beta 2 \ln L_{i t}+\beta 3 \ln M_{i t}+\beta 4 \ln F S_{i t}+\beta 5 \text { Horizontal }_{j t}+ \\
& +\beta 6 \text { Backward }_{j t}+\beta 7 \text { Forward }_{j t}+\alpha_{t}+\alpha_{r}+\alpha_{j}+\varepsilon_{i j r t}
\end{aligned}
$$

where:

$Y_{i t}$ is the firm productivity, measured as the firm i's real output at time $t$. The value of this indicator comes from the volume of the sales of a firm deflated by the PPI for the appropriate two-digit NACE sector;

$K_{i t}$, or capital, is calculated as the value of fixed assets of the firm, deflated by the average of the deflators for four NACE sectors (machinery and equipment; office, accounting and computing machinery; electrical machinery and apparatus; motor vehicles, trailer and semi-trailers; and other transport equipment);

$L_{i t}$, or employment, is the number of workers of the firm; 
$M_{i t}$, or material inputs, are defined as the value of material inputs of the company at the beginning of the year deflated by a sector deflator based on the input-output matrix for the corresponding two-digit NACE sectors;

$F S_{i p}$ is the share of foreign capital in firm's total capital; this indicator stands for the foreign investment.

Horizontal $_{i t}$ is a variable that measures the degree of a foreign presence in the sector, to which the firm belongs. This variable is defined as a share of foreign capital in the equity capital of the firm (FDI), divided by the quantity of firms in the sector and weighted by the share of each firm in the entire sector output:

$$
\text { Horizontal }_{j t}=\left[\sum i \text { for all } i \in j F S_{i j t} \times Y_{i j t}\right] / \sum i \text { for all } i \in j Y_{i j t}
$$

Backward $_{j t}$ variable proxies the foreign presence in the sectors supplied by the sector, to which the current firm belongs using the cross-sector input-output table:

$$
\text { Backward }_{j t}=\sum k \text { if } k \neq j \alpha_{j k} \text { Horizontal }_{j p}
$$

where $\alpha_{j k}$ is the part of sector $\mathrm{j}$ output supplied to sector $k$ taken from the input-output matrix at the two-digit NACE level.

Forward $_{j t}$ variable shows the presence of firms with foreign capital in the sectors supplying the current sector:

$$
\text { Forward }_{j t}=\sum m \text { if } m \neq j \gamma_{j m} \text { Horizontal }_{j p}
$$

where $\gamma_{j m}$ is the part of inputs, bought by sector $j$ from sector $m$ in the total inputs purchased by sector $j$, taken from the input-output matrix at the two-digit NACE level.

\section{Data description}

The study is based on Amadeus panel datasets at firm level. The time frames include a period from 2002 to 2011. The number of firms is 8371 for Estonia, 11120 for Latvia, and 14067 for Lithuania, however, some of them were omitted during the estimation process because of the lack of some rows of data. The dataset covers enterprises from all range of sectors according to NACE classification. NACE inputoutput tables were taken from the Eurostat database.

\section{Estimation results}

In this section the estimation results from the OLS regression for the firms from Latvia, Lithuania and Estonia are shown and analyzed. The outcomes are reported in Table 2.

The results show that the productivity spillovers from FDI are significant in the case of the Baltic countries. Horizontal spillovers are negative in all cases, which confirms the idea that the spillovers of FDI are vertical by nature as foreign investors 
Table 2. OLS estimation results for Latvia, Lithuania and Estonia

\begin{tabular}{|l|c|c|c|}
\hline & Estonia & Latvia & Lithuania \\
\hline$K$ & 0.0287 & 0.0790 & 0.8587 \\
& $(0.0018)$ & $(0.0014)$ & $(0.0030)$ \\
\hline$M$ & 0.2669 & 0.6395 & 0.4502 \\
& $(0.0032)$ & $(0.0030)$ & $(0.0050)$ \\
\hline FS & 0.1265 & 0.0193 & $($ omitted) \\
& $(0.0015)$ & $(0.0040)$ & \\
\hline Horizontal & -0.0186 & 0.0224 & 0.0543 \\
& $(0.0016)$ & $(0.0022)$ & $(0.0031)$ \\
\hline Forward & -0.4283 & -0.7391 & -0.1151 \\
& $(0.0024)$ & $(0.0018)$ & $(0.0040)$ \\
\hline Backward & -0.1223 & 0.3658 & -0.1575 \\
& $(0.0074)$ & $(0.0044)$ & $(0.0110)$ \\
\hline Constant & 1.0819 & 0.7976 & 0.1595 \\
& $(0.0077)$ & $(0.0054)$ & $(0.0110)$ \\
\hline Number of observations & 0.1723 & 0.3055 & 0.3778 \\
\hline$R^{2}$ & $(0.0081)$ & $(0.0053)$ & $(0.0113)$ \\
\hline
\end{tabular}

Standard errors in parentheses.

Level of significance: $p<0.01$.

Source: own estimations based on the Amadeus data.

tend to keep their technology and know-how is at a secret. We can observe strictly negative effect in case of Latvia. It can happen so because of the fact that domestic companies cannot stand the increased competition after the entrance of foreign companies under the conditions of an economic integration, thus their sales growth and productivity decrease. As to the vertical spillovers, a completely different picture can be remembered. Forward spillovers are negative in case of Estonia and Lithuania, while in case of Latvia we can observe significant positive effects. It means that effects from purchasing from foreign firms are mostly negative in case of Estonia and Lithuania. This fact supports the hypothesis defined in the introduction for the case of small post-soviet countries. However, positive signals from Latvia point at the greater efficiency of the domestic firms, using inputs from foreign-owned companies.

Also we can see positive backward spillovers in all three countries. This fact means that foreign companies tend to cooperate with domestic enterprises instead of importing their supplies from abroad. This result contradicts some previous research, 
in particular by Javorcik, Saggi and Spatareanu [2004]. It can be explained by the fact that local companies can offer inputs of good quality but at a lower price than traditional suppliers of the MNCs in their home countries.

\section{Conclusions}

The outcomes of the research show that productivity spillovers from FDI exist in case of the Baltic countries, but they do not behave always in appliance with the theory. Indeed, horizontal spillovers are negative in all reviewed countries, but forward spillovers have negative sign in two out of three cases. At the same time, backward linkages are strongly positive showing that the Baltic countries do benefit from foreign capital inflow. The estimation results indicate that for the transitive economies, integrated into the EU, forward spillovers can be negative and this can be explained by the fact that domestic firms, not satisfying the EU standards, are replaced by foreign companies from the EU countries that offer the same products of higher standards but at higher prices. Such a combination of prerequisites will reduce the productivity of local producers buying these inputs. It can be presumed that due to the narrowness of local market, local exporters, working with the EU countries tend to buy inputs from producers with foreign capital. However, foreign investors, especially from the EU countries tend to buy inputs locally, because of lower prices comparing with their traditional suppliers and this can explain rather high values of backward spillovers in the Baltic countries. In general it gives the following picture: for small open economies accessing the EU negative forward spillovers combined with positive backward externalities are rather natural. At the same time the transitive character of their economies makes horizontal spillovers obligatorily negative because of the fact that still not all of the enterprises use modern technologies, management techniques, or marketing strategies. However, it can also be assumed that the deepening of integration processes will diminish the values of negative effects as the development of local firms and their adaptation to the standards of the EU is just a matter of time.

\section{References}

Aitken B., Harrison A., 1999, Do domestic firms benefit from direct foreign investment? Evidence from Venezuela, American Economic Review, Vol. 89(3), pp. 605-618.

Blalock G., 2001, Technology from foreign direct investment: strategic transfer through supply chains, Working paper, University of California, Haas School of Business, Berkeley.

Blomström M., 1986, Foreign investment and productive efficiency: the case of Mexico, Journal of Industrial Economics, Vol. 35, pp. 97-110.

Blomström M., Kokko A., 1998, Multinational corporations and spillovers, Journal of Economic Surveys, Vol. 12(3), pp. 247-277. 
Blomström M., Globerman S., Kokko A., 2000, The determinants of host country spillovers from foreign direct investment, CEPR discussion paper, No. 2350, Centre for Economic Policy Research, London.

Caves R., 1974, Multinational firms, competition and productivity in host-country markets, Economica, Vol. 41, pp. 176-193.

Crespo N., Fontoura M.P., 2007, Determinant factors of FDI spillovers - what do we really know?, World Development, Vol. 35 (3), pp. 410-425.

Damijan J., Knell M., Majcen B., Rojec M., 2003, Technology transfer through FDI in top-10 transition countries: how important are direct effects, horizontal and vertical spillovers, William Davidson Working Paper, Vol. 549, The University of Michigan Business School.

Damijan J., Majcen B., Rojec M., Knell M., 2013, Impact of firm heterogeneity on direct and spillover effects of FDI: micro-evidence from ten transition countries, Journal of Comparative Economics, Vol. 41, pp. 895-922.

Djankov S., Hoekman B., 2000, Foreign investment and productivity growth in Czech enterprises, World Bank Economic Review, Vol. 14(1), pp. 49- 64.

Du L., Harrison A., Jefferson G.H., 2012, Testing for horizontal and vertical foreign investment spillovers in China, 1998-2007, Journal of Asian Economics, Vol. 23, pp. 234-243.

Dunning J., 1993, Multinational Enterprises and the Global Economy, Addison-Wesley Publishing Company, Wokingham.

Javorcik B., 2004, Does foreign direct investment increase the productivity of domestic firms? In search of spillovers through backward linkages, American Economic Review, Vol. 94(3), pp. 605-627.

Javorcik B., Saggi K., Spatareanu M., 2004, Does it matter where you come from? Vertical spillovers from foreign direct investment and the nationality of investors, World Bank Policy Research Working Paper, No. 3449, Washington, DC.

Konings J., 2001, The effects of foreign direct investment on domestic firms: evidence from firm-level panel data in emerging economies, Economics of Transition, Vol. 9(3), pp. 619-633.

Lipsey R., 2002, Home and host country effects of FDI, NBER Working Paper, No. 9293, National Bureau of Economic Research, Cambridge.

Merlevede B., Schoors K., Spatareanu M., 2013, FDI spillovers and time since foreign entry, BOFIT Discussion Papers, No. 27/2013, Bank of Finland, Institute for Economies in Transition.

Rhee Y., Belot T., 1990, Export catalysts in low-income countries: a review of eleven success stories, World Bank Discussion Papers, No. 72, Washington, D.C.

Schoors K., van der Tol B., 2001, Foreign direct investment spillovers within and between sectors: evidence from Hungarian data, Working Paper, No. 2002/157, University of Gent.

Stancik J., 2009, FDI spillovers in the Czech Republic: takeovers vs. greenfields, Economic Papers, No. 369, The European Commission.

Suyanto S., Salim R., 2013, Foreign direct investment spillovers and technical efficiency in the Indonesian pharmaceutical sector: firm level evidence, Applied Economics, Taylor \& Francis Journals, Vol. 45(3), pp. 383-395.

Suyanto S., Salim R., Bloch H., 2012, Foreign direct investment spillovers and productivity growth in Indonesian garment and electronics manufacturing, Journal of Development Studies, Taylor \& Francis Journals, Vol. 48(10), pp. 1397-1411.

Xu X., Sheng Y., 2012, Productivity spillovers from foreign direct investment: firm-level evidence from China, World Development, Elsevier, Vol. 40(1), pp. 62-74. 